J. MED. MICROBIOL.-VOL. 17 (1984), 273-282

C. 1984 The Pathological Society of Great Britain and Ireland

\title{
REACTIONS OF EXTRACTS OF REITER TREPONEME WITH SYPHILITIC AND NON-SYPHILITIC HUMAN SERA IN THE SINGLE RADIAL HAEMOLYSIS TECHNIQUE
}

\section{A. A. Al-Qudah and Ann Mostratos}

\section{Department of Bacteriology and Virology, Medical School, University of Manchester, Oxford Road, Manchester M13 9PT}

\begin{abstract}
SUmmaRY. A single radial haemolysis ( $\mathrm{SRH}$ ) technique, using Reiter protein or Reiter lysate as the coating antigen, was investigated. Results obtained with syphilitic and presumed non-syphilitic human sera were compared with results obtained in the absorbed fluorescent treponemal antibody test (FTA-ABS), the Reiter protein complement fixation test (RPCFT), the Venereal Diseases Research Laboratory Slide test (VDRL) and the Cardiolipin Wasserman reaction (CWR). The SRH reaction, with either Reiter antigen, was more sensitive than any of the screening tests (RPCFT, VDRL and CWR) for detecting positive syphilitic antibodies. Although the SRH test used almost the same materials as the RPCFT, it was appreciably more sensitive for the detection of the group-specific antibodies in syphilitic human serum.
\end{abstract}

\section{INTRODUCTION}

Laboratory tests for the diagnosis of syphilis rely mainly on serological techniques to detect antibodies in the patient's serum or cerebrospinal fluid. Techniques utilising Treponema pallidum antigens include the Treponema pallidum immobilisation test (TPI) (Nelson and Mayer, 1949), the fluorescent treponemal antibody test (FTA) (Deacon, Freeman and Harris, 1960), the improved FTA (FTA-ABS) (Hunter, Deacon and Meyer, 1964) and the Treponema pallidum haemagglutination test (TPHA) (Rathlev, 1967). The TPI test is technically difficult (Wilkinson and Johnston, 1959) and is now rarely used. The FTA-ABS test is specific and sensitive (Blum et al., 1973) and is the confirmatory test of choice, although it requires a high level of expertise and expensive equipment. The TPHA test is simple and rapid to perform, although it may be insensitive in primary syphilis (O'Neill, 1976) and some preparations may give a high proportion of false negative results (MacFarlane and Elias-Jones, 1977; Al-Qudah and Mostratos, 1982).

The protein antigen shared by $T$. pallidum and Reiter's treponeme (D'Alessandro and Dardanoni, 1953) has been utilised in tests for the diagnosis of syphilis, e.g., Reiter protein complement fixation test (RPCFT), but has not been exploited to its maximum potential. Antibodies to this group-specific antigen are present in sera of all syphilitic patients and some healthy individuals (Deacon and Hunter, 1962; Niel and 
Fribourg-Blanc, 1963). Wilkinson and Rayner (1966) reported that, except in early infections, the titre of such antibodies may equal or even exceed the titre of antibodies specific for $T$. pallidum.

We have explored the use of Reiter protein and a lysate of Reiter's treponeme as coating antigen in the single radial haemolysis (SRH) technique (Schild, Pereira and Chakraverty, 1975), a method not previously applied to the diagnosis of syphilis but which offers a relatively simple way of detecting group-specific antibodies. In the SRH test, antigen-coated red cells are incorporated in a gel layer and wells are then cut in the gel and filled with the sera under test. Serum antibodies diffusing from the wells react with the antigen and, in the presence of complement added later, produce a zone of haemolysis which is measured easily. Using sera from syphilitic and non-syphilitic patients, we have made a preliminary assessment of the diagnostic value of the SRH method by comparison with some of the established screening methods used in syphilis serology.

\section{MATERIALS AND METHODS}

\section{Sera}

A total of 203 selected sera were used, of which 108 were from patients with a clinical and serological diagnosis of syphilis who were attending the special treatment clinic, Manchester Royal Infirmary, and 95 were from presumed healthy volunteers; each sample was inactivated by heating at $56^{\circ} \mathrm{C}$ for $30 \mathrm{~min}$ before being tested.

\section{Antigens}

Reiter protein. Reiter treponemes (received from Wellcome Research Laboratories) were grown on the modified thioglycollate medium recommended by Christiansen (1963) but without agar and resazurin. After incubation at $37^{\circ} \mathrm{C}$ for 5-6 days, growth was deposited by centrifugation and washed four times in $0.1 \% \mathrm{w} / \mathrm{v}$ azide-saline; the resulting button was suspended in the proportion of $1 \mathrm{~g}$ of wet cells to $20 \mathrm{ml}$ of phosphate buffered saline (PBS), $p \mathrm{H} 7 \cdot 2$, and the protein fraction of the organism was prepared according to the method of Tomizawa, Kasamatsu and Yamaya (1969), by ammonium sulphate precipitation from suspensions of organisms disrupted by ultrasonication. The resulting antigen was preserved with sodium azide $0.1 \%$ and kept in small portions at $-20^{\circ} \mathrm{C}$. When in use, the antigen preparation was kept at $4^{\circ} \mathrm{C}$.

Reiter lysate. Reiter treponemes were grown as above and, after washing with azide-saline, the cells were resuspended in distilled water to give a density equivalent to Brown's Opacity Standard No. 3. The suspension, cooled in ice, was sonicated in a Rapidis 300 ultrasonic machine for 10-15 min. After centrifugation at $500 \mathrm{rpm}$ for $5 \mathrm{~min}$, the supernate was harvested and preserved by the addition of sodium azide to a final concentration of $0 \cdot 1 \% \mathrm{w} / \mathrm{v}$. Stock antigen was kept in small volumes at $-20^{\circ} \mathrm{C}$; antigen in use was kept at $4^{\circ} \mathrm{C}$. The antigen was then titrated by coating small quantities of standard tanned erythrocytes (see below) with decreasing amounts (increasing dilutions) of antigen and testing these by SRH against known positive and negative sera (Wellcome Reagents Ltd, positive and negative control sera). The working dilution of the antigen was taken as that giving the largest clear zone of haemolysis around the well of positive serum and no haemolysis around the negative serum. The titre of the Reiter protein antigen was generally 15 , and that of the Reiter lysate was generally 10 .

\section{Preparation of red blood cells}

Fresh citrated blood cells from adult domestic male fowls were centrifuged and washed three times in PBS $(p \mathrm{H} 7 \cdot 2)$ and resuspended at a concentration of $3 \% \mathrm{v} / \mathrm{v}$ in normal saline. 


\section{Tanning of cells}

One volume of $3 \%$ fowl red cells was added to one volume of 1 in $20000 \mathrm{w} / \mathrm{v}$ tannic acid $(\mathrm{BDH})$ in saline and the mixture was incubated for $10 \mathrm{~min}$ at $37^{\circ} \mathrm{C}$, being shaken at least once. The mixture was then centrifuged at $1500 \mathrm{rpm}$; the sedimented cells were washed once with saline and resuspended to a concentration of $3 \% \mathrm{v} / \mathrm{v}$ in saline.

\section{Sensitization of red cells with Reiter antigen}

Equal volumes of $3 \%$ tanned cells and the required dilution, in PBS, $p \mathrm{H} 6 \cdot 4$, of Reiter antigen were mixed and kept at $37^{\circ} \mathrm{C}$ for $30 \mathrm{~min}$, with shaking every $10 \mathrm{~min}$. These were the test cells. Control cells were similarly prepared, but with PBS instead of antigen. Both test and control cells were centrifuged at low speed for 3-4 min, washed once with saline and finally resuspended to a concentration of $9 \% \mathrm{v} / \mathrm{v}$ in CFT diluent (Oxoid).

\section{Preparation of gel plates}

A suspension of agarose $1 \% \mathrm{w} / \mathrm{v}$ (Koch-Light Laboratories Ltd, Colnbrook, Bucks) in CFT diluent was melted in boiling water and cooled to $45-50^{\circ} \mathrm{C}$. To $2.6 \mathrm{ml}$ of the molten agarose suspension was added $0.3 \mathrm{ml}$ of $9 \%$ tanned and coated red cells. The mixture was shaken vigorously and quickly poured into a $5-\mathrm{cm}$ diam. sterile plastic Petri dish and allowed to set.

\section{Standard procedure for single radial haemolysis ( $S R H)$}

Wells of $4 \mathrm{~mm}$ diam. were punched in the solidified gel with a metal punch and each was filled with $15 \mu \mathrm{l}$ of serum which had been inactivated at $56^{\circ} \mathrm{C}$ for $30 \mathrm{~min}$. Six wells could be accommodated in the 5-cm Petri dish used. Plates were placed in a humid chamber at $4^{\circ} \mathrm{C}$ for $24 \mathrm{~h}$ and then $1 \mathrm{ml}$ of a 1 in 10 dilution of complement (Guinea pig serum preserved by Richardson's method and freeze-dried; Wellcome Reagents Ltd) was added to cover the surface of each plate; the plate was then shaken at $37^{\circ} \mathrm{C}$ for $45-60 \mathrm{~min}$. The zones of haemolysis could be seen by the naked eye and were measured easily. Control plates containing uncoated red cells (control cells) were always used in parallel.

In any case where the zone was hazy, or was doubtful, the plate was left at $4^{\circ} \mathrm{C}$ overnight and read again; zones that were clearer than before were considered positive; those that remained the same were considered negative.

\section{Other tests}

Several of the conventional serological tests for syphilis were also performed on the same serum samples that were tested by SRH. These were the Cardiolipin Wassermann reaction (CWR), Venereal Diseases Research Laboratory (VDRL) slide test, Reiter protein complement fixation test (RPCFT), and the fluorescent treponemal antibody (FTA-ABS) test. Most of the reagents were from Wellcome Reagents Ltd and the techniques followed the recommendations of the manufacturers, except for the FTA-ABS test which was performed as described by Wilkinson (1972).

\section{RESULTS}

\section{Investigation of test variables}

The variables in the single radial haemolysis technique were examined systematically.

Antigen. Against syphilis-positive and -negative human sera, 1 in 10 and 1 in 15 dilutions of Reiter protein gave equally satisfactory results (table I). At higher dilutions up to 1 in 60 , haemolytic zones of similar size but decreased clarity were 
TABLE I

Effect of dilution of coating antigen (Reiter protein) on SRH results with syphilis-positive and syphilis-negative human sera

\begin{tabular}{|c|c|c|c|c|c|}
\hline \multirow{4}{*}{$\begin{array}{l}\text { Antigen } \\
\text { dilution }\end{array}$} & \multicolumn{5}{|c|}{ Results obtained with } \\
\hline & \multicolumn{4}{|c|}{ Syphilis-positive serum } & \multirow{3}{*}{$\begin{array}{c}\text { Syphilis } \\
\text { negative } \\
\text { serum }\end{array}$} \\
\hline & \multicolumn{3}{|c|}{$\begin{array}{l}\text { Zone diameter }(\mathrm{mm}) \text { after } \\
\text { incubation }\left(37^{\circ} \mathrm{C}\right) \text { for }\end{array}$} & \multirow{2}{*}{$\begin{array}{l}\text { Clarity } \\
\text { of zone }\end{array}$} & \\
\hline & $24 \mathrm{~h}$ & $48 \mathrm{~h}$ & $72 \mathrm{~h}$ & & \\
\hline 1 in 10 & 11 & $13 \cdot 8$ & 14 & +++ & - \\
\hline 1 in 15 & 11 & $13 \cdot 6$ & $14 \cdot 5$ & +++ & - \\
\hline 1 in 20 & 11 & 13 & 14 & ++ & - \\
\hline 1 in 40 & 11 & 14 & 14 & + & - \\
\hline 1 in 60 & 11 & 14 & 14 & + & - \\
\hline 1 in 80 & - & - & - & - & - \\
\hline
\end{tabular}

$+++=$ very good, clear zones of haemolysis

$++=$ clear and easily read zones of haemolysis;

$+=$ weak haemolysis;

$-=$ no zone of haemolysis after $72 \mathrm{~h}$ at $37^{\circ} \mathrm{C}$.

obtained with positive sera; there was no haemolysis beyond a 1 in 60 dilution. There was no haemolysis with uncoated control cells and positive or negative sera. In the interests of economy, therefore, a 1 in 15 dilution of Reiter protein antigen was used routinely. Reiter lysate tested in the same way gave similar results at 1 in 5 and 1 in 10 dilutions; there were clear zones with positive sera $(9-10.5 \mathrm{~mm}$ diam. in $24 \mathrm{~h}$ ), but at the 1 in 20 dilution, zones were of poorer clarity and there was no haemolysis at the 1 in 40 dilution. The Reiter lysate was therefore used routinely at a dilution of 1 in 10 .

Tannic acid. Table II shows the results of diluting the tannic acid solution used in

\section{TABLE II}

Effect of dilution of tannic acid (used to prepare fowl red cells for coating with a 1 in 15 dilution of Reiter protein antigen) on SRH results with syphilis-positive and syphilis-negative sera

\begin{tabular}{|c|c|c|c|c|c|}
\hline \multirow{4}{*}{$\begin{array}{l}\text { Tannic } \\
\text { acid } \\
\text { dilution }\end{array}$} & \multicolumn{5}{|c|}{ Results obtained with } \\
\hline & \multicolumn{4}{|c|}{ Syphilis-positive serum } & \multirow{3}{*}{$\begin{array}{c}\text { Syphilis- } \\
\text { negative } \\
\text { serum }\end{array}$} \\
\hline & \multicolumn{3}{|c|}{$\begin{array}{l}\text { Haemolytic zone diameter } \\
(\mathrm{mm}) \text { after incubation } \\
\left(37^{\circ} \mathrm{C}\right) \text { for }\end{array}$} & \multirow{2}{*}{$\begin{array}{c}\text { Clarity } \\
\text { of } \\
\text { zone }\end{array}$} & \\
\hline & $24 \mathrm{~h}$ & $48 \mathrm{~h}$ & $72 \mathrm{~h}$ & & \\
\hline $\begin{array}{l}1 \text { in } 10000 \\
1 \text { in } 20000 \\
1 \text { in } 40000 \\
1 \text { in } 50000 \\
1 \text { in } 80000 \\
1 \text { in } 100000\end{array}$ & $\begin{array}{l}11 \cdot 7 \\
11 \cdot 8 \\
12 \\
12 \\
12 \\
12 \cdot 5\end{array}$ & $\begin{array}{l}12 \cdot 3 \\
11 \cdot 7 \\
13 \cdot 5 \\
13 \cdot 5 \\
14 \\
14\end{array}$ & $\begin{array}{l}14 \cdot 5 \\
14 \cdot 5 \\
15 \\
15 \\
15 \cdot 5 \\
15 \cdot 5\end{array}$ & $\begin{array}{l}++^{*} \\
+++ \\
+++ \\
++ \\
+ \\
+\end{array}$ & $\begin{array}{l} \pm \dagger \\
- \\
- \\
- \\
-\end{array}$ \\
\hline
\end{tabular}

See footnote to table I for explanation of symbols.

* Plates showed aggregates of red blood cells throughout the gel.

$\uparrow$ Traces of haemolytic zones were observed after $48 \mathrm{~h}$. 
preparing cells for coating with Reiter protein. Concentrations of tannic acid stronger than 1 in 20000 resulted in auto-agglutination of red cells and traces of haemolysis where none was expected. Optimal results were obtained with 1 in 20000 and 1 in 40000 dilutions of tannic acid, but the former were more reproducible and the 1 in 20000 dilution was therefore used routinely. Almost identical results were obtained when Reiter lysate was used as the coating antigen. There was no haemolysis with control cells that were treated with dilutions of tannic acid above 1 in 10000 but not coated with Reiter protein in tests with positive or negative sera, although cells treated with a 1 in 10000 dilution gave a trace of haemolysis with both types of sera.

Complement. With the 5-cm Petri dish used, $1 \mathrm{ml}$ of a 1 in 10 dilution of guinea-pig serum covering the agar surface gave optimal results in terms of zone size and clarity. Using sufficient diluted serum only to fill the wells resulted in very poor zones, and sometimes none at all, even after prolonged incubation.

Agarose. Identical results were obtained with $1 \%$ and $1.5 \% \mathrm{w} / \mathrm{v}$ concentrations of agarose in preliminary tests, and $1 \%$ was therefore used routinely.

Erythrocytes. Three concentrations each of sheep and fowl red blood cells were investigated. The results given in table III illustrate that either type of red cell could be used and that the lowest concentration of cells tested $(0.3 \mathrm{ml}$ of $9 \% \mathrm{v} / \mathrm{v}$ per plate $)$ was the best in terms of zone clarity. Similar results were obtained with red cells coated with a 1 in 10 dilution of Reiter lysate. There was no haemolysis with uncoated control cells and positive or negative sera. Fowl red cells were used routinely, because they were more readily available and gave somewhat clearer zones of haemolysis than did sheep cells.

Temperature. In preliminary tests, temperatures of $37^{\circ} \mathrm{C}$ and $4^{\circ} \mathrm{C}$ were compared for holding plates after the addition of serum to the wells, but before the addition of complement. Non-specific haemolysis occurred in the plates held at $37^{\circ} \mathrm{C}$ for $24 \mathrm{~h}$, often, even in the absence of added complement. However, in plates held at $4^{\circ} \mathrm{C}$ for $24 \mathrm{~h}$, non-specific haemolysis was eliminated. Therefore, plates were held for $24 \mathrm{~h}$ at $4^{\circ} \mathrm{C}$ after the addition of sera to wells, and incubated at $37^{\circ} \mathrm{C}$ after the addition of complement.

TABLE III

Effect of type and concentration of red blood cells (coated with Reiter protein diluted) 1 in 15 on $S R H$ results with serum from a known syphilitic patient

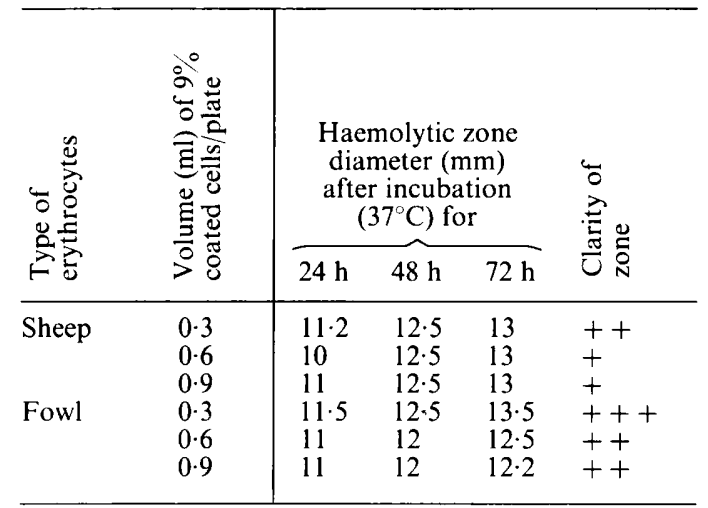




\section{Reproducibility and other observations}

Variation between gel plates prepared at the same time and between plates prepared on different days was investigated. In both cases, haemolytic zone size for a given test was reproducible; the largest difference in diameter was $0.8 \mathrm{~mm}$, undoubtedly ascribable to errors in filling wells or in measuring zones.

With a few sera, a very narrow but sharp haemolytic zone was observed directly around the wells in both test and control plates. It was more easily seen with a hand lens, whereas the large haemolytic zones produced by positive sera were quite clear to the naked eye. Prozones were also noted with a few positive sera; these were unlysed zones immediately surrounding the well and inside the haemolytic zones, and their sizes varied according to those of the proper haemolytic zone, being larger with larger haemolytic zones.

Gel plates prepared with either of the Reiter antigens gave the same results on day 10 of storage at $4^{\circ} \mathrm{C}$ in a moist atmosphere as on day 1 . Thereafter the clarity of the zones decreased because of general haemolysis in the plates, which became unusable by day 12 .

\section{Comparison of SRH with other tests}

The 203 selected sera were used undiluted in SRH-L (Reiter lysate), SRH-P (Reiter protein) and VDRL tests, and diluted 1 in 5 in the CWR, RPCFT and FTA-ABS tests. The results are summarised in table IV, where the sensitivity of each test is indicated in terms of percentage positive for each group of sera. Investigation of two supposedly negative serum samples (from volunteers) that gave positive reactions only with SRH-L showed that they were from cases treated for primary syphilis 4 years previously. The numbers were adjusted to take account of this, so that results are presented for 110 syphilitic and 93 presumed non-syphilitic patients' sera.

The most sensitive and specific test was the FTA-ABS $(98 \%)$ which was performed twice, independently, on each specimen of serum and taken to be a reliable confirmative test. This was followed by SRH-L which had a $91 \%$ sensitivity, giving 10

TABLE IV

Results of serological tests for syphilis on single sera from 110 syphilitic and 93 presumed non-syphilitic individuals

\begin{tabular}{|c|c|c|c|c|c|c|}
\hline \multirow{3}{*}{ Test* } & \multicolumn{6}{|c|}{ Results obtained with sera from } \\
\hline & \multicolumn{3}{|c|}{ Patients with syphilis (110) } & \multicolumn{3}{|c|}{ Presumed normal subjects (93) } \\
\hline & $\begin{array}{l}\text { Number } \\
\text { positive }\end{array}$ & $\begin{array}{l}\text { Number } \\
\text { negative }\end{array}$ & $\begin{array}{l}\text { Percentage } \\
\text { sensitivity }\end{array}$ & $\begin{array}{l}\text { Number } \\
\text { positive }\end{array}$ & $\begin{array}{l}\text { Number } \\
\text { negative }\end{array}$ & $\begin{array}{c}\text { Percentage number } \\
\text { of false } \\
\text { positive results }\end{array}$ \\
\hline FTA-ABS & 108 & 2 & 98 & 0 & 93 & 0 \\
\hline SRH-L & 100 & 10 & 91 & 0 & 93 & 0 \\
\hline SRH-P & 97 & 13 & 88 & 0 & 93 & 0 \\
\hline RPCFT & 79 & 31 & 72 & 6 & 87 & 6 \\
\hline VDRL & 62 & 48 & 56 & 16 & 77 & 17 \\
\hline CWR & 54 & 56 & 49 & 3 & 90 & 3 \\
\hline
\end{tabular}

* See Methods 


\section{TABLE V}

Comparison of sensitivity of various serological tests with 110 sera from treated and untreated patients at different stages of syphilis

\begin{tabular}{llc|cccccc}
\hline & & \multicolumn{6}{|c}{ Percentage sensitivity of } \\
\cline { 5 - 9 } $\begin{array}{l}\text { Stage of } \\
\text { disease }\end{array}$ & $\begin{array}{c}\text { State of } \\
\text { treatment }\end{array}$ & $\begin{array}{c}\text { Number of } \\
\text { cases }\end{array}$ & FTA-ABS & SRH-P & RPCFT & VDRL & CWR & SRH-L \\
\hline Primary & Treated & 13 & 85 & 85 & 54 & 23 & 38 & 92 \\
syphilis & Untreated & 4 & 100 & 100 & 75 & 75 & 75 & 100 \\
Secondary & Treated & 20 & 100 & 90 & 90 & 65 & 55 & 90 \\
syphilis & Untreated & 3 & 100 & 100 & 100 & 100 & 100 & 100 \\
$\begin{array}{l}\text { Latent } \\
\text { syphilis }\end{array}$ & Treated & 38 & 100 & 87 & 68 & 68 & 53 & $89 \cdot 5$ \\
$\begin{array}{l}\text { Congenital } \\
\text { syphilis }\end{array}$ & Treated & 8 & 100 & $87 \cdot 5$ & 50 & 25 & 25 & $87 \cdot 5$ \\
Stage not & Treated & 14 & 100 & 86 & 71 & 36 & 43 & 93 \\
specified & Untreated & 10 & 100 & 90 & 80 & 70 & 40 & 90 \\
TOTAL & Treated & 93 & 97 & 87 & 70 & 53 & 48 & 90 \\
& Untreated & 17 & 100 & 94 & 82 & $76 \cdot 5$ & 59 & 94 \\
\hline
\end{tabular}

\section{TABLE VI}

Comparison of titres obtained by RPCFT and VDRL tests, with haemolytic zone diameters ( $\mathrm{mm}$ ) in SRH-P tests with 10 sera

\begin{tabular}{c|ccc}
\hline Serum no. & $\begin{array}{c}\text { VDRL } \\
\text { titre }\end{array}$ & $\begin{array}{c}\text { RPCFT } \\
\text { titre }\end{array}$ & $\begin{array}{c}\text { SRH-P haemolytic } \\
\text { zone diam. (mm) }\end{array}$ \\
\hline 118 & $<2$ & 5 & $9 \cdot 6$ \\
47 & 2 & 5 & 9.0 \\
83 & 4 & 10 & 10.5 \\
109 & 4 & 20 & $11 \cdot 0$ \\
99 & 8 & 10 & 10.5 \\
101 & 8 & 20 & 11.0 \\
95 & 16 & 40 & 12.5 \\
121 & 32 & 80 & 13.0 \\
149 & 64 & 160 & 13.5 \\
120 & $<2$ & 160 & 15.0 \\
\hline
\end{tabular}

"false negative" results (i.e., it failed to detect 10 positive sera). SRH-P failed to detect 13 positive sera, 12 of which were from treated cases of various stages of syphilis. Table V provides a comparison of the sensitivity of the six tests at different stages of syphilis.

We originally included the Wellcome TPHA test in the comparative tests, but it performed so poorly in our hands (Al-Qudah and Mostratos, 1982) that we have excluded the results.

A few randomly-chosen positive sera were titrated by VDRL, RPCFT and SRH-P and the results are shown in table VI. The largest SRH zones were given by the sera with the highest titres in other tests (apart from serum 120), but even sera with low titres gave large, easily visible zones. There may be a linear relationship between the $\log _{2}$ RPCFT titre and the haemolytic zone diameter. 


\section{Discussion}

Passive haemagglutination, i.e., antibody agglutination of erythrocytes with appropriate microbial or non-microbial antigens attached to their surfaces, has been used widely as a means of detecting or measuring antibodies directed against the coating antigens (Herbert, 1973). However, passive haemolysis techniques, requiring complement, have not been so fully exploited.

The single radial haemolysis technique has been very helpful in diagnostic virology, especially for the detection of specific antibodies against haemagglutinating viruses, which attach to red cells without the intervention of tannic acid (Schild et al., 1975; Forger and Gilfillan, 1979). The virological techniques incorporate excess complement in the gel layer, but this was found not to work with Reiter antigens and the complement had to be added later, as a superficial layer. Plates shaken after the addition of complement produced haemolytic zones more quickly than did unshaken plates.

The initial incubation temperature was very important in the SRH test. At $37^{\circ} \mathrm{C}$ overnight, in the presence of human serum, non-specific haemolysis occurred in the absence of added complement. This is in agreement with the observations of Hinz and Pillemer (1955) that normal human erythrocytes treated with weak solutions of tannic acid were haemolysed at $37^{\circ} \mathrm{C}$ by human serum. Therefore, the diffusion of the test serum was performed at $4^{\circ} \mathrm{C}$, with satisfactory results.

Although SRH uses almost the same materials as RPCFT, it is appreciably more sensitive for the detection of the group-specific antibodies in human syphilitic sera. Its greater sensitivity may be due to the higher concentration of serum used. The large number of "false negatives" (i.e., positive sera not detected) obtained with the RPCFT is due to the prozone effect (Bekker, 1962); a prozone was seen with some sera in SRH but within the proper haemolytic zone. The occurrence of prozones in this type of test was reported by Strannegard, Grillner and Lindberg (1975) and Russell, McCahon and Beare (1975) but not explained. A possible explanation is that the higher concentration of antibodies in the immediate vicinity of the wells may result in the red cells being covered by an excess of antibody molecules, creating a physical barrier that denies complement access to the red cells. As the serum diffuses further from the wells, the antibody concentration will become lower, allowing complement activation to occur.

The SRH reaction was very sensitive for detecting syphilis. It was interesting that SRH-P gave no reactions with the supposedly negative sera, and that only SRH-L reacted with two of these sera that were subsequently identified as being from patients that had once had syphilis. SRH-P and SRH-L failed to give haemolysis with approximately the same number of proven positive syphilitic human sera, the majority of which were from treated cases. During this investigation, therefore, the SRH method gave fewer false positives and negatives than the screening tests CWR, VDRL and RPCFT.

The zones obtained with positive sera in SRH were readily visible and measurable, with diameters of 9-15 mm. Their clarity increased if plates were kept overnight at $4^{\circ} \mathrm{C}$, but not if they were held at $37^{\circ} \mathrm{C}$. Cunniff and Stollar (1968) obtained higher titres in the RPCFT with a pooled human serum if the complement fixation was allowed to proceed at $4^{\circ} \mathrm{C}$, rather than at $37^{\circ} \mathrm{C}$. They found that a serum fraction 
containing 19S antibodies gave negligible titres at either $4^{\circ} \mathrm{C}$ or $37^{\circ} \mathrm{C}$; another fraction, containing $7 \mathrm{~S}$ antibodies, gave $73.1 \%$ of the original titre at $4{ }^{\circ} \mathrm{C}$, and $58.7 \%$ at $37^{\circ} \mathrm{C}$. Irrespective of the nature of the antibodies involved, the reactions (RPCFT and SRH) appear to proceed optimally at $4^{\circ} \mathrm{C}$, although the complement-mediated lysis of the red cells proceeds optimally at $37^{\circ} \mathrm{C}$.

A major advantage of the SRH technique is that only one well in the test plate and one in the control plate are needed for each serum sample, which does not require dilution. Because clear zones are obtained even with sera giving low titres in other tests (table VI), measurement of zone size would not be important for diagnostic purposes. Plates can be prepared in a central supply laboratory and then used by unskilled personnel. Although we used only $5-\mathrm{cm}$ plates with 6 wells, there is no reason to doubt the feasibility of performing the reaction in larger plates.

Not many sera have been investigated in the present exercise but the results indicate the possibility that SRH could be of value for screening purposes in syphilis serology. The Reiter lysate antigen would detect more of the positive cases and is easier to prepare than Reiter protein.

We gratefully acknowledge the co-operation of the staff of the special treatment clinic, Manchester Royal Infirmary, who provided us with the specimens of patients' sera. We are also indebted to Mr D. Coupes and Mrs C. Bradburn for their kind help.

\section{REFERENCES}

Al-Qudah A A, Mostratos A 1982 The Reiter Haemagglutination (RHA) Test: A screening test for syphilis. British Journal of Venereal Diseases 58:281-285.

Bekker J H 1962 Limitations of the Reiter Protein Complement Fixation (RPCF) Test. British Journal of Venereal Diseases 38:131-133.

Blum G, Ellner P D, McCarthy L R, Papachristos T 1973 Reliability of the treponemal hemagglutination test for the serodiagnosis of syphilis. Journal of Infectious Diseases 127:321-324.

Christiansen A H 1963 The Reiter strain of Treponema pallidum. Origin, cultivation and use in immunization of rabbits. Acta Pathologica et Microbiologica Scandinavica 57:81-86.

Cunniff R V, Stollar B D 1968 Properties of 19S antibodies in complement fixation. I. Temperature dependence and role of antigen structure. Journal of Immunology 100:7-14.

D'Alessandro G, Dardanoni L 1953 Isolation and purification of the protein antigen of the Reiter treponeme. A study of its serologic reactions. American Journal of Syphilis 37:137-150.

Deacon W E, Freeman E M, Harris A 1960 Fluorescent treponemal antibody test. Modification based on quantitation (FTA-200). Proceedings of the Society for Experimental Biology and Medicine 103:827-829.

Deacon W E, Hunter E F 1962 Treponemal antigens as related to identification and syphilis serology. Proceedings of the Society for Experimental Biology and Medicine 110:352-356.

Forger J M, Gilfillan R F 1979 Single radial hemolysis as a cost effective determinant of Rubella antibody status. Journal of Clinical Microbiology 9:115-119.

Herbert W J 1973 Passive haemagglutination with special reference to the tanned cell technique. In: Weir D M (ed) Handbook of experimental Immunology, 2nd edn. Blackwell, Oxford, pp 20.1-20.16.

Hinz C F, Pillemer L 1955 The requirement for the properdin system in the hemolysis of human erythrocytes treated with tannic acid. Journal of Clinical Investigation 34:912.

Hunter E F, Deacon W E, Meyer P E 1964 An improved FTA test for syphilis; the absorption procedure (FTA-ABS). Public Health Reports 79:410-412.

MacFarlane D E, Elias-Jones T F 1977 Screening tests for syphilis. A comparison of the 
Treponema pallidum haemagglutination assay with two automated serological tests. British Journal of Venereal Diseases 53:348-352.

Niel G, Fribourg-Blanc A 1963 Immuno-Fluorescence et sérologie de la syphilis. Bulletin of the World Health Organization 29:429-442.

Nelson R A, Mayer M M 1949 Immobilization of Treponema pallidum in vitro by antibody produced in syphilitic infection. Journal of Experimental Medicine 89:369-393.

O'Neill P 1976 A new look at the serology of treponemal diseases. British Journal of Venereal Diseases 52:296-299.

Rathlev T 1967 Haemagglutination test utilizing pathogenic Treponema pallidum for the serodiagnosis of syphilis. British Journal of Venereal Diseases 43:181-185.

Russell S M, McCahon D, Beare A S 1975 A single radial haemolysis technique for the measurement of influenza antibody. Journal of General Virology 27:1-10.

Schild G C, Pereira M S, Chakraverty P 1975 Single radial haemolysis: a new method for the assay of antibody to influenza haemagglutinin. Applications for diagnosis and seroepidemiologic surveillance of influenza. Bulletin of the World Health Organization 52:43-50.

Strannegård O, Grillner L, Lindberg I M 1975 Haemolysis-in-gel test for the demonstration of antibodies to rubella virus. Journal of Clinical Microbiology 1:491-494.

Tomizawa T, Kasamatsu S, Yamaya S 1969 Usefulness of the haemagglutination test using Treponema pallidum antigen (TPHA) for the serodiagnosis of syphilis. Japanese Journal of Medical Science and Biology 22:341-350.

Wilkinson A E 1972 Serological tests for syphilis. In: Laboratory diagnosis of venereal disease. Public Health Laboratory Service Monograph Series No. 1. H.M.S.O., London pp 1-24.

Wilkinson A E, Johnston N A 1959 Results of parallel tests with the Reiter protein complement fixation test, the Treponemal immobilization test, and the treponemal Wassermann reaction on 1,046 sera. British Journal of Venereal Diseases 35:175-180.

Wilkinson A E, Rayner C F A 1966 Studies on the fluorescent treponemal antibody (FTA) test. British Journal of Venereal Diseases 42:8-15. 